\title{
COMPARATIVE FORENSIC ANALYSIS OF GUNSHOT INJURIES CAUSED BY 8X57MM CARTRIDGES EQUIPPED WITH GECO, RWS AND SELLIER\&BELLOT EXPANDING BULLETS
}

\author{
N. V. Bartoshyk
}

Abstract: The paper discusses the results of the experimental study of the gunshot injuries caused by $8 \times 57 \mathrm{~mm}$ cartridges equipped with expanding bullets from different manufacturers to biological and non-biological objects at various distances. Forensic description of the common and distinctive morphological features is presented.

Key words: gunshot injuries, expanding bullets, shooting distance, fabric damage.

УДК 340.6: 614.23/.25: 616-036.8

\section{ЕКСПЕРТНА ОЦНКА НАДАННЯ МЕДИЧНОЇ ДОПОМОГИ ПРИ ТРАВМАХ, ЗАХВОРЮВАННЯХ ТА ОТРУСННЯХ У РІЗНИХ ВІДДІЛЕННЯХ БАГАТОПРОФІЛЬНОЇ ЛІКАРНІ ШВИДКОЇ МЕДИЧНОЇ ДОПОМОГИ}

\author{
СПлетенецька А. О., Гуріна О. О., Попов В. А., Рощін Г. Г. \\ НМАПО імені П. Л. Шупика
}

\begin{abstract}
Резюме. Одними з найскладніших судово-медичних експертиз $є$ експертизи, що стосуються визначення правильності надання медичної допомоги. Метою дослідження було проведення аналізу медичної документації хворих у випадках розбіжностей клінічного та судово-медичного діагнозів по основному та ускладненням для виявлення основних причин невірно встановленого діагнозу за даними багатопрофільної лікарні швидкої та невідкладної медичної допомоги за 2006-2012 рр. Після статистичної обробки даних була проведена експертна оцінка летальності багатопрофільної лікарні, що включала у себе більш детальне вивчення надання медичної допомоги пацієнтам. Зокрема, виділялися причини невірно встановленого клініцистами діагнозу, а також порівнювалися випадки неспівпадінь основного клінічного діагнозу з судово-медичним у випадках наявності травми, захворювання або отруєння. Після цього оцінювалася медична допомога, зокрема і медикаментозне лікування, яке було призначено лікарями. Ці дані співставлялися з тим, яка медична допомога була реально потрібна хворим з урахуванням безпосередньою причиною смерті.
\end{abstract}

Ключові слова: судово-медична експертиза, надання медичної допомоги, травма, захворювання, отруєння.

ВСТУП. Провідну роль в розслідуванні злочинів, що були вчинені під час надання медичної допомоги лежить на судово-медичній експертизі. Проведення експертиз з приводу дефектів надання медичної допомоги регулюється Законом України «Про судову експертизу» від 25 лютого 1994 р. № 4038-ХІІ та Інструкції «Про проведення судово-медичної експертизи», затвердженої наказом Міністерства охорони здоров'я України від 17 січня 1995 р. № $6[2,3]$. Одними з найскладніших судово-медичних експертиз є експертизи, що стосуються визначення правильності надання медичної допомоги. Основними причинами цього є недостатня кількість нормативних актів, що регулювали б надання медичної допомоги населенню, та недосконалістю правової бази $[1,7,8]$. Для об'єктивної та вірної оцінки надання медичної допомоги судово-медичним експертам, на яких покладено таке завдання, слід ретельно вивчати всі тонкощі цієї допомоги на кожному етапі з урахуванням вимог чинного законодавства України $[4,5,6]$. Для вирішення питань щодо надання медичної допомоги потрібно проаналізувати у динаміці на кожному етапі обсяг, тактику, повноту, своєчасність призначених хворому лікувально-діагностичних заходів.

Метою дослідження було проведення аналізу медичної документації хворих у випадках розбіжностей клінічного та судово-медичного діагнозів по основному та ускладненням для виявлення основних причин невірно встановленого діагнозу за даними багатопрофільної лікарні швидкої та невідкладної медичної допомоги (ЛШНМД) за 2006-2012 pp.

Матеріали і методи. Матеріалом досліджень були 207 медичних карток стаціонарних хворих, що знаходились на лікуванні враховувалися наступні показники: відділення (токсикологічне, нейрохірургічне, відділення полі травми, відділення інтенсивної терапії та екстреної допомоги (ВIT та ЕД), травматологічне, невідкладної терапії), стать та вік хворого, дата госпіталізації, дата смерті, тривалість лікування, час госпіталізації, час настання смерті, ким був направлений хворий (ШМД, поліклініка, самозвернення), діагноз з супровідного листа ШМД, якими спеціалістами був оглянутий хворий, які аналізи додаткові методи обстеження проводилися, клінічний діагноз (основний, ускладнення, супутній, судово-медичний діагноз, розходження діагнозів по основному та по ускладненням (повне та неповне), причина цього розходження. Обробка та аналіз даних проводилися в програмних пакетах OpenOffice (Base, Calc, Writer, Draw, Math), GNU Octave зі збереженням вихідних документів у форматі *.doc, *.xls. 
РЕЗУЛЬТАТИ ДОСЛІДЖЕННЯ ТА ЇХ ОБГОВОРЕННЯ.

При статистичному аналізі 207 медичних карток стаціонарних хворих, що знаходились на лікуванні у різних відділеннях ЛШНМД, було виявлено наступне. При лікуванні пацієнтів у різних відділеннях комплекс аналізів, додаткових досліджень та оглядів спеціалістів при однакових діагнозах був різним виключно у всіх випадках, що підтверджую відсутність єдиного підходу до діагностики патологічних станів. 3 іншого ж боку, мінімальний обсяг досліджень був обумовлений по наступним причинам: 1. короткий час знаходження хворих у стаціонарі при тяжких патологіях; 2. затримка у проведенні досліджень з невідомих причин за наявності показань.

У таблиці 1 встановлені діагнози у різних відділеннях було розподілено на три групи: захворювання, травма та отруєння. При цьому співпадіння клінічного та судово-медичного діагнозів (захворювання-захворювання, травма-травма, отруєння-отруєння) склало загалом 21 (10,1\%), неповне співпадіння - 42 (20,3\%), неспівпадіння $-144(69,6 \%)$.

У відділенні токсикології у 53,9 \% ставився діагноз отруєння, у той час, як причиною смерті було захворювання (53,9 \%). Тут найбільш частими клінічними діагнозами з вказаних були отруєння алкоголем та невідомою речовиною (загалом 9 випадків- 69,2%), що стало безпосередньою причиною смерті лише у 2х випадках. У решті ж випадків безпосередньою причиною смерті стали панкреанекроз, цироз печінки та переохолодження. При оцінці лікування слід зазначити, що воно, зазвичай відповідало клінічному діагнозу. Втім, при панкреанекрозі хворі потребували ще і оперативного втручання, а при ураженнях печінки- призначення гепатотропних препаратів, чого зроблено не було. Що ж стосується фактичної причини смерті від переохолодження, то лікування не було обрано вірно, а було спрямовано тільки на дезінтоксикацію. Слід зазначити, що з 13 випадків по даному відділенню один діагноз лікарями ставився в 6 випадках (46,2\%), причому з них тільки в 2х випадках клінічний співпадав 3 судово-медичним- отруєння та захворювання. У решті ж випадків лікарями встановлювалося 2 та більше діагнозів, причому у більшості випадків (61,5\%) діагноз все ж таки не був встановлений вірно.

Групи діагнозів, встановлених у різних відділеннях ЛшнМД

\begin{tabular}{|c|c|c|c|c|}
\hline \multirow[t]{2}{*}{ Відділення } & \multirow[t]{2}{*}{$\begin{array}{c}\text { Співпадіння } \\
\text { n (\%) }\end{array}$} & \multirow{2}{*}{$\begin{array}{c}\text { Неповне } \\
\text { співпадіння } \\
\text { n (\%) }\end{array}$} & \multicolumn{2}{|c|}{$\begin{array}{c}\text { Неспівпадіння } \\
\text { n (\%) }\end{array}$} \\
\hline & & & $\begin{array}{c}\text { Суд-мед } \\
\text { діагноз }\end{array}$ & $\begin{array}{c}\text { Клін. } \\
\text { діагноз }\end{array}$ \\
\hline I. Токсикологічне (13) & $2(15,4)$ & $3(23,1)$ & \multicolumn{2}{|l|}{$8(61,5)$} \\
\hline захворювання & $1(7,7)$ & $2(15,4)$ & $7(53,9)$ & $1(7,7)$ \\
\hline Травма & - & - & - & - \\
\hline Отруєння & - & $1(7,7)$ & $1(7,7)$ & $7(53,9)$ \\
\hline II. Нейрохірургічне (54) & - & $9(16,7)$ & \multicolumn{2}{|c|}{$45(83,3)$} \\
\hline захворювання & - & $6(11,1)$ & $42(77,8)$ & $2(3,7)$ \\
\hline Травма & - & $3(5,6)$ & $2(3,7)$ & $42(77,8)$ \\
\hline Отруєння & - & - & $1(1,9)$ & $1(1,9)$ \\
\hline III. Політравми (31) & - & $3(9,7)$ & \multicolumn{2}{|c|}{$27(90,3)$} \\
\hline захворювання & - & $2(6,5)$ & $27(87,1)$ & - \\
\hline Травма & - & - & $1(3,2)$ & $26(83,9)$ \\
\hline Отруєння & - & $1(3,2)$ & - & $2(6,5)$ \\
\hline IV. ВIT та ЕД (90) & $18(20,0)$ & $19(21,1)$ & \multicolumn{2}{|c|}{$53(58,9)$} \\
\hline Захворювання & $3(3,3)$ & $8(8,9)$ & $46(51,2)$ & $4(4,4)$ \\
\hline Травма & - & $3(3,3)$ & $6(6,6)$ & $5(5,5)$ \\
\hline Отруєння & $15(16,7)$ & $8(8,9)$ & $2(2,2)$ & $44(49,0)$ \\
\hline V.Травматологічне (11) & - & $3(27,3)$ & \multicolumn{2}{|c|}{$8(72,7)$} \\
\hline Захварювання & - & $3(27,3)$ & $8(72,7)$ & - \\
\hline Травма & - & - & - & $7(63,6)$ \\
\hline Отруєння & - & & - & $1(9,1)$ \\
\hline VI. Невідкл. терапії (8) & $1(12,5)$ & $5(62,5)$ & \multicolumn{2}{|c|}{$2(37,5)$} \\
\hline Захворювання & $1(12,5)$ & $5(62,5)$ & $1(12,5)$ & $1(12,5)$ \\
\hline Травма & - & - & $1(12,5)$ & $1(12,5)$ \\
\hline Отруєння & - & - & - & - \\
\hline Всього & $21(10,1)$ & $42(20,3)$ & \multicolumn{2}{|c|}{$144(69,6)$} \\
\hline
\end{tabular}


У відділенні нейрохірургії у 77,8\% ставився діагноз травми, у той час, як причиною смерті було захворювання (77,8\%). Тут найбільш частими клінічними діагнозами з вказаних була ЗЧМТ (39 випадків 354 ) різних форм-72,2 \%, причому у $23,1 \%$ з них безпосередньою причиною смерті було цереброваскулярне захворювання, а у $17,9 \%$-переохолодження. У решті випадків судово-медичні діагнози були найрізноманітнішими. При оцінці лікування слід зазначити, що у випадках причини смерті від цереброваскулярного захворювання за наявності клінічного діагнозу ЧМТ лікувально-діагностична тактика загалом була обрана вірно. Що ж стосується решти випадків, то лікувально-діагностичні заходи було обрано згідно встановленим діагнозам, що зовсім не відповідало фактично наявній у хворих патології. Слід зазначити, що у всіх випадках по даному відділенню лікарями встановлювалося 2 та більше діагнозів, причому жодного діагнозу повністю не збіглося з судово-медичним.

У відділенні політравми у 83,9\% ставився діагноз травми, у той час, як причиною смерті було захворювання $(87,1 \%)$. Тут найбільш частими клінічними діагнозами з вказаних були закрита травма грудей та живота (загалом 19 випадків 331 - 61,3\%) при найрізноманітніших варіантах безпосередньої причини смерті, найчастіше 3 яких все ж таки був панкреанекроз (36,8 \%). При оцінці лікування лікувально-діагностичні заходи було обрано згідно встановленим діагнозам, що зовсім не відповідало фактично наявній у хворих патології. Слід зазначити, що з 31 випадку по даному відділенню один діагноз лікарями ставився в 1 випадку. У решті ж випадків лікарями встановлювалося 2 та більше діагнозів, причому у більшості випадків $(90,7 \%)$ діагноз все ж таки не був встановлений вірно.

У відділенні ВІТ та ЕД у 49,0\% ставився діагноз отруєння, у той час, як причиною смерті було захворювання $(53,9 \%)$. Тут ставилися майже завжди діагнози отруєння, у тому числі алкоголем та його сурогатами, наркотичними, невідомими речовинами, подеколи із ураженням підшлункової та печінки (загалом 93,3%) при безпосередній причині смерті від панкреанекрузу, циррозу печінки, печінкової та ниркової недостатності. При цьому лікування у відділенні було спрямоване на детоксикацію. Втім, у цьому відділенні за наявності ниркової недостатності не ставиться питання щодо доцільності обстеження хворих для наступного проведення гемодіалізу. Слід зазначити, що з 90 випадків по даному відділенню один діагноз лікарями ставився в 32 випадках $(35,6 \%)$, причому з них тільки в 18 (20 \%) випадках клінічний співпадав з судово-медичним (переважна більшість 3 них 15 випадків- по отруєнням і тільки 3 випадки- по захворюванню). У решті ж випадків лікарями встановлювалося 2 та більше діагнозів, причому у більшості випадків (58,9\%) діагноз все ж таки не був встановлений вірно.

У відділенні травматології у 63,6\% ставився діагноз травми, у той час, як причиною смерті було захворювання $(53,9 \%)$. Тут найбільш частими клінічними діагнозами з вказаних були скелетна травма (6 випадків з 11- 54,5 \%) при безпосередній причині смерті від різноманітних захворювань (частіш за все це було цереброваскулярне захворювання та панкреанекроз - по 2 випадки кожного). При оцінці лікування лікувально-діагностичні заходи було обрано згідно встановленим діагнозам, що зовсім не відповідало фактично наявній у хворих патології. Слід зазначити, що з 11 випадків по даному відділенню один діагноз лікарями ставився тільки в 1 випадку,який не співпав з судово-медичним. У більшості випадків (72,7\%) діагноз не був встановлений вірно.

У відділенні невідкладної терапії були одиничні випадки, коли травму плутали з захворюванням і навпаки. Тут клініцистами у половині випадків (50\%) було встановлено переохолодження при безпосередній причині смерті від панкреанекрозу. Лікування при цьому не відповідало такому, що було необхідним при панкреанекрозі. Слід зазначити, що з 8 випадків по даному відділенню один діагноз лікарями ставився тільки в 1 випадку, який співпав з судово-медичним- по захворюванню. У більшості випадків (62,5\%) діагноз не повністю співпадав.

У випадках співпадінь діагнозів клініцистів та судово-медичного експерта лікування відповідало встановленим діагнозам. У випадках неповного співпадіння судово-медичного і клінічного діагнозів лікування, у цілому, було призначене відповідно до одного чи двох із встановлених клініцистами діагнозів. Що ж стосується тих випадків, коли діагнозів було більше, то лікування, фактично, було спрямованим також на 1-2 патології і зовсім не стосувалося інших виставлених діагнозів. Якщо оцінювати доцільність лікування, то воно хоча і не було протипоказане, втім не могло значно полегшити стан хворого. У випадках неспівпадінь діагнозів лікування було лікарями обрано тактично вірно тільки у випадках смерті від цереброваскулярної патології при клінічному діагнозі ЧМТ.

При оцінці лікування, яке було проведено на догоспітальному етапі (бригадами ШМД), можна сказати, що воно було симптоматичним і було спрямовано на стабілізацію стану хворого. Діагноз медичними працівниками ШМД встановлювався посиндромально, втім медикаментозне лікування, що проводиться на догоспітальному етапі, майже не відрізняється у всіх випадках. Це, можливо, пов'язано з нестачею препаратів у працівників ШМД. Слід також зазначити, що у жодному випадку працівниками ШМД не було діагностовано пневмонію. У той же час від пневмонії померло 2 хворих у токсикологічному відділенні, 6- у нейрохірургічному, 2- у політравмі, 4- у ВIT та ЕД, 2- у травматологічному та 1- у невідкладній терапії. При цьому, з 17 випадків у клінічному діагнозі лікарі встановили наявність пневмонії тільки у 5 (2- у відділенні нейрохірургії, по 1- у травматологічному відділенні та невідкладній терапії).

Неспівпадіння трьох діагнозів (ШМД, клінічного та судово-медичного) спостерігалося тільки у відділенні ВІТ та ЕД. 
При аналізі діагнозів, які встановлювалися співробітниками ШМд, було виявлено, що вони співпадали 3 клінічним діагнозом: у відділенні токсикології у 23,1% (3), у нейрохірургічному - у 72,2 \% (39), у політравмі - у 71 \% (22), у ВІТ та ЕД - у 56,7 \% (51), у травматологічному - у 90,9 \% (10), у невідкладній терапії - у 25 \% (2). При аналізі медичної документації загалом було виявлено недостатньо описаний соматичний стан хворого, що свідчить про низьку якість оформлення медичної документації.

\title{
ВИСНОВКИ та перспективи подальших досліджень
}

1.Таким чином, у всіх відділеннях лікарями встановлювався переважно діагноз травми (або отруєння) коли причиною смерті було захворювання. У той же час, враховуючи відсутність необхідних досліджень для підтвердження травматичного генезу, можна сказати, що такі діагнози виставляються лікарями необ'єктивно.

2.Вищевказане підтверджується також і великою питомою вагою недіагностованих а ні на догоспітальному етапі, а ні у відділеннях пневмонією, яка ставала причиною смерті. Тобто захворювання погано діагностувалися клініцистами, а лікування у відділенні спрямовано, здебільшого, не на лікування основної патології, а на загальний напрям відділення, що підкреслює недостатню обізнаність лікарів у різних галузях медицини, оскільки кожен з фахівців орієнтується на патології «свого» профілю і призначає відповідне лікування.

3.Лікування, що було призначено хворим було етіопатогенетично обрано тільки у небагатьох випадках: випадки повного співпадіння діагнозів, а також неповних і неспівпадінь за наявності цереброваскулярної патології (при клінічному діагнозі ЗЧМТ) і частково- при отруєннях. Це можна пояснити тим, що лікування встановленої клініцистами патології майже не відрізнялося від насправді наявної у хворих.

4.Таким чином, рівень надання медичної допомоги в Україні вкрай низький, що пов'язано, насамперед, з відсутністю злагодженої та організованої роботи медичних працівників як на догоспітальному, так і на госпітальному етапі.

\section{Література}

1. Дунаєвська Л.Г. Розслідування злочинів, вчинених під час надання медичної допомоги / Дунаєвська Л.Г. // Монографія. - К.: АДС УМКЦентр, 2012. - 168 с.

2. Закон України «Про судову експертизу» [Електронний ресурс]/ Відомості Верховної Ради України (ВВР) - К., 2004, - № 28- ст.232 - Режим доступу: http://zakon.rada.gov.ua- Назва з екрану.

3. Інструкція про проведення судово-медичної експертизи, затверджена наказом Міністерства охорони здоров'я України від 17.01.95 р. N 6 [Електронний ресурс]/ Міністерство охорони здоров’я України - К., 1995. -№ 6. - Режим доступу: http://zakon1.rada.gov.ua- Назва з екрану.

4. Кримінальний процесуальний кодекс України [Електронний ресурс]/ Відомості Верховної Ради України (ВВР) - К., 2014, - № 46. -ст.2046- Режим доступу: http://zakon2.rada.gov.ua- Назва з екрану.

5. Кримінальний кодекс України [Електронний ресурс]/ Міністерство охорони здоров'я України - К., 2001. -№ 25-26. - Режим доступу: http://zakon1.rada.gov.ua- Назва з екрану.

6. Правила судово-медичного визначенняступеня тяжкості тілесних ушкоджень // Наказ Міністерства охорони здоров’я України “Про розвиток та вдосконалення судово-медичної служби України”. - 17 січня 1995 р., № 6. - К.: МОЗ України, 1995. - С. 83-88.

7. Стеблюк В.В. Правові та морально-етичні аспекти кримінальних правопорушень у сфері професійної діяльності медичних працівників // Судово-медична експертиза - К., 2013. - № 2. - С.- 45- 48.

8. Стеценко С.Г. Медичне право України: підручник / С. Г. Стеценко, В. Ю. Стеценко, І. Я. Сенюта; за заг. ред. д.ю.н., проф. С. Г. Стеценка. - К.: Всеукраїнська асоціація видавців «Правова єдність», 2008. - 507 с.

\section{ЭКСПЕРТНАЯ ОЦЕНКА ОКАЗАНИЯ МЕДИЦИНСКОЙ ПОМОЩИ ПРИ ТРАВМАХ, ЗАБОЛЕВАНИЯХ И ОТРАВЛЕНИЯХ В РАЗНЫХ ОТДЕЛЕНИЯХ МНОГОПРОФИЛЬНОЙ БОЛЬНИЦЫ СКОРОЙ МЕДИЦИНСКОЙ ПОМОЩИ}

\author{
Плетенецкая А. А., Гурина О. А., Попов В. А., Рощин Г. Г.
}

Резюме. Проведен анализ медицинской документации больных в случаях расхождений клинического и судебно-медицинского диагнозов по основному и осложнениям для выявления основных причин неверно установленного диагноза по данным многопрофильной больницы скорой и неотложной медицинской помощи за 2006-2012 г.г. Проведена экспертная оценка летальности многопрофильной больницы, включающая в себя более детальное изучение оказания медицинской помощи пациентам. Выделялись причины неверно установленного клиницистами диагноза, а также сравнивались случаи несовпадений основного клинического диагноза с судебно-медицинским в случаях наличия травмы, заболевания или отравления. После этого оценивалась медицинская помощь, в том числе и медикаментозное лечение, которое было назначено врачами. Эти данные сопоставлялись с тем, какая медицинская помощь была реально нужна больным с учетом непосредственной причины смерти.

Ключевые слова: судебно-медицинская экспертиза, оказание медицинской помощи, травма, заболевание, отравление. 


\title{
EXPERT ASSESSMENT OF MEDICAL CARE IN CASES OF INJURY, ILLNESS AND POISONING IN DIFFERENT DEPARTMENTS OF HOSPITAL OF AMBULANCE MEDICAL CARE
}

\author{
Pletenetska A., Gurina O., Popov V. A., Roshin G.
}

\begin{abstract}
Summary. One of the most complex forensic examinations is the determination of the correct medical care. The aim of the study was an analysis of medical records of patients in the cases of divergence of clinical and forensic diagnoses on the main complications and to identify the main causes of incorrect diagnosis established in a hospital of ambulance medical care for the 2006 2012. Expert assessment of mortality General Hospital was carried out after statistical data processing, including a more detailed study of patient care. In particular, stood out the reasons of incorrectly clinical diagnosis, cases of discrepancy of the main clinical diagnosis with forensic diagnosis were compared in cases of injury, disease or poisoning. After that evaluated medical care, including medical treatment, which was prescribed by a doctor. These data were compared with those which medical aid was really necessary in patients with considering the immediate cause of death.
\end{abstract}

Keywords: forensic examination, medical care, injury, dise.

УДК: 616.12-005.4-073.55

\section{ДОСЛІДЖЕННЯ БІОЛОГІЧНИХ ТКАНИН І РІДКИХ СЕРЕДОВИЩ ОРГАНІЗМУ ЛЮДИНИ ЛАЗЕРНИМИ ПОЛЯРИМЕТРИЧНИМИ МЕТОДАМИ}

\author{
СБачинський В. Т., Ушенко О. Г., Ванчуляк О. Я., Саркісова Ю. В. \\ Кафедра судової медицини та медичного правознавства \\ Буковинський державний медичний університет, Чернівці
}

Резюме. У статті представлений сучасний стан питання діагностики патологічних станів для судово-медичних експертів практиків. Особливу увагу приділено біофізичними методам дослідження, які володіють доказовою точністю, об'єктивністю, відтворюваністю та високою швидкістю отримання результату. Перспективним, на наш погляд, є дослідження рідких середовищ організму людини, зокрема скловидного тіла, методами лазерної поляриметрії, що дозволяють виявити та впровадити в практику новітні оптичні критерії діагностики давності настання смерті. не тіло.

Ключові слова: лазерна поляриметрія, давність настання смерті, час формування гематом, ішемія міокарда, скловид-

ВСТУП. За останні роки ми спостерігаємо тенденцію до розвитку нових сучасних методик дослідження біологічних тканин (БТ) і середовищ організму (СО) людини. Зокрема в судово-медичній практиці існує низка питань, які не можуть бути вирішені без розробки нових підходів до діагностики патологічних станів.

Одним із потужних методів досліджень структури і властивостей препаратів БТ та СО є поляризаційна мікроскопія (ПМ). ІІЇ використання можливе на основі того, що всі тканин організму людини можна представити, як сукупність оптично одноосних протеїнових фібрил, що володіють здатністю подвійного променезаломлення та формують його унікальну структурно-функціональну організацію $[11,13]$.

Для реалізації методу ПМ можна дооснастити будь-який мікроскоп: додати два поляризаційні фільтри (перший поміщають безпосередньо під конденсором, другий - між об'єктивом і оком дослідника). Для затемнення поля зору проводять поворот поляризатора, в подальшому зміщують досліджуваний об'єкт на предметному столику до появи яскравого світіння (воно з'являється в момент перебування вісі двопроменезаломлюючого об’ єкта під кутом $45^{\circ}$ до площини поляризації) [9].

ПМ на етапах свого розвитку пройшла поступове удосконаленням методики: спочатку застосування фільтрів із лінійною, а в подальшому - з циркулярною поляризацією. Встановлено, що зображення, отримані за допомогою циркулярних фільтрів, несуть набагато більше інформації, дозволяють більш детально вивчити структуру тканин $[9,12]$.

Протягом останніх років ПМ шляхом міжгалузевої інтеграції медицини, оптичної фізики та аналітичної математики трансформувалась у лазерну поляриметрію. Колективом кафедри судової медицини та медичного правознавства Буковинського державного медичного університету та кафедри оптики та спектроскопії інженернотехнічного факультету Чернівецького національного університету імені Ю. Федьковича було прийняте рішення, слідуючи за загальносвітовою тенденцією, впровадити дану методику в галузь судово-медичної діагностики та розробити принципово новий підхід для вирішення складних завдань в практиці судово-медичних експертів. Дана методика забезпечує потужну діагностичну цінність у поєднанні з об'єктивністю, відтворюваністю та швидкістю отримання результату $[1,2,4]$. 